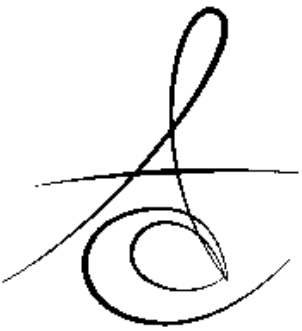

THE EVALUATION OF BOND STRENGTH BETWEEN DENTAL CERAMIC AND BASE METAL ALLOYS FABRICATED BY CASTING AND LASER SINTERING ${ }^{*}$

\title{
LAZER SİNTERLEME VE DÖKÜM YÖNTEMİ İLE İMAL EDİLMİş BAZ METAL ALAŞIMLARIN DENTAL SERAMİKLER İLE BAĞLANMA DAYANIMININ DEĞERLENDİRİLMESİ ${ }^{\neq}$
}

\author{
Doç. Dr. Yurdanur UÇAR* \\ Doç. Dr. Orhun EKREN \\ Dr. Elif Figen KOÇAK*
}

Makale Kodu/Article code: 3935

Makale Gönderilme tarihi: 17.12.2018

Kabul Tarihi: 17.05.2019

\section{ABSTRACT}

Aim: The aim of this study was to evaluate bond strength of laser sintered $\mathrm{Co}-\mathrm{Cr}$ and cast $\mathrm{Co}-\mathrm{Cr}$ and Ni$\mathrm{Cr}$ alloys to porcelain using 3-point-bending test (3PB test).

Material and Methods: 3 different metal frameworks were used in the current study: laser sintered $\mathrm{Co}-\mathrm{Cr}$, cast $\mathrm{Co}-\mathrm{Cr}$ and cast $\mathrm{Ni}-\mathrm{Cr}$. Fifteen specimens per group were prepared according to ISO 9693 standard (1999) and tested using 3PB test. Results were analyzed using one-way ANOVA followed by Tukey multiple comparison test $(a=0,05)$.

Results: Mean bending modulus and flexural bending strength were statistically significantly different among 3 groups $(P=0,0001)$. The lowest mean bending modulus was observed for laser sintered $\mathrm{Co}-\mathrm{Cr}$ group $(77 \pm 6,5 \mathrm{GPa})$ and the highest value was observed for cast Co-Cr group (247 $\pm 16 \mathrm{GPa}$ ). Pairwise comparisons have shown statistically significant differences between all compared groups. When mean bending strength values were compared, the highest value was

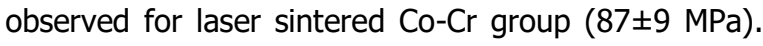
Although mean flexural strength value of cast $\mathrm{Co}-\mathrm{Cr}$ group (78 $\pm 13 \mathrm{MPa}$ ) was lower than the laser sintered one, the difference was not statistically significant $(P=0,094)$. However, the mean bending strength of cast $\mathrm{Ni}-\mathrm{Cr}(45 \pm 11 \mathrm{MPa})$ was significantly lower than the Co-Cr groups $(P=0,0001)$.

Conclusion: Within the limitations of this study, it can be concluded that laser sintered $\mathrm{Co}-\mathrm{Cr}$ frameworks establish a strong bond with porcelain.

Key Words: Rapid manufacturing, CAD/CAM, Laser Sintering, Casting, Bond Strength

\section{ÖZET}

Amaç: Bu çalışmanın amacı lazer sinterize $\mathrm{Co}-\mathrm{Cr}$ ve döküm yöntemi ile elde edilen $\mathrm{Ni}-\mathrm{Cr}$ ve $\mathrm{Co}-\mathrm{Cr}$ alaşımlarının porselen ile bağlantısını 3-nokta-bükme testi (3-Point-Bending; 3PB) kullanarak değerlendirmektir.

Gereç-Yöntem: Çalışmada metal altyapı olarak 3 farklı grup kullanılmıştır: lazer sinterize $\mathrm{Co}-\mathrm{Cr}$, döküm $\mathrm{Co}-\mathrm{Cr}$ ve döküm $\mathrm{Ni}-\mathrm{Cr}$. Her grup için 15 örnek ISO 9693(1999) standartlarına uygun olarak hazırlanmış ve 3PB testi kullanılarak bağlanma dayanımı değerlendirilmiştir. Veriler ANOVA ve sonrasında Tukey çok yönlü karşılaştırma testi kullanılarak değerlendirilmiştir $(a=0,05)$.

Bulgular: Bükülme modülü ve ortalama en yüksek bükme dayanımı değerleri karşılaştırıldığında her iki parametre için 3 grup arasında istatistiksel fark bulunmuştur $(P=0,0001)$. En düşük ortalama bükülme modülü lazer sinterize grupta gözlenirken $(77 \pm 6,5$ $\mathrm{GPa}$ ), en yüksek değer döküm $\mathrm{Co}-\mathrm{Cr}$ grubunda

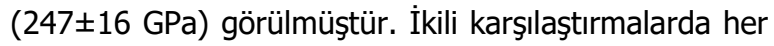
3 grup da birbirinden farklı bulunmuştur. Ortalama bükülme dayanımı değerleri karşılaştırıldığında ise en yüksek dayanım değeri lazer sinterize $\mathrm{Co}-\mathrm{Cr}(87 \pm 9$ $\mathrm{MPa}$ ) grubunda bulunurken, döküm $\mathrm{Co}-\mathrm{Cr}$ grubunun bükülme dayanımı ( $78 \pm 13 \mathrm{MPa}$ ) daha düşük olmakla birlikte aradaki farkın istatistiksel açıdan anlamlı olmadığı görülmüştür $(P=0,094)$. Ancak döküm $\mathrm{Ni}-\mathrm{Cr}$ grubunun ortalama bükülme dayanımı değeri (45 \pm 11 $\mathrm{MPa}$ ) $\mathrm{Co}-\mathrm{Cr}$ gruplarından anlamlı şekilde daha düşük bulunmuştur $(P=0,0001)$.

Sonuç: Bu çalışmanın sınırları dâhilinde lazer sinterize Co-Cr altyapılarının porselen ile güçlü bir bağlantı oluşturduğu sonucuna varılmıştır.

Anahtar kelimeler: Hızlı Üretim, CAD/CAM, Lazer Sinterleme, Döküm, Bağlanma Dayanımı

\footnotetext{
*Çukurova Üniversitesi Diş Hekimliği Fakültesi Protetik Diş Tedavisi ABD, Adana

₹12-15 Kasım 2015 tarihinde Antalya'da gerçekleştirilen 22. Uluslararası Türk Prostodonti ve İmplantoloji Derneği Bilimsel Kongresinde sözlü sunum olarak tebliğ edilmiştir.
} 


\section{INTRODUCTION}

The bond strength between metal framework and dental porcelain is mandatory for satisfactory clinical life of metal-ceramic restorations. ${ }^{1,2}$ Various alloys are successfully used for fabricating these restorations. $^{3}$ Noble alloys are superior for biocompatibility. However, base metal alloys ( $\mathrm{Co}-\mathrm{Cr}$ and $\mathrm{Ni}-\mathrm{Cr}$ ) are material of choice due to affordability. ${ }^{4,5}$

Common method for fabricating metal frameworks is called "lost wax" technique. It is also known as conventional casting. ${ }^{6}$ Conventional casting is replaced by rapid manufacturing methods that are known as computer aided design and manufacturing (CAD/CAM) techniques. ${ }^{7,8}$ One of the most recent rapid manufacturing methods for fabricating metalceramic frameworks is direct metal laser sintering (DMLS). With this method, specially produced very fine alloy powders are fused together to construct the desired object layer by layer using laser beam. ${ }^{7,8}$ This system has been used for a long time in industries like automotive and aerospace because of advantages like producing hollow and complicated structures with standard sizes in decreased amount of time. ${ }^{9-10}$ During the last decade DMLS has been used for dental applications.

There are various kinds of metal powder compositions used for DMLS in dental applications. ${ }^{11}$ Single component pure metal powders, alloy powders and the mixture of metal powders with high and low melting temperatures can be used for DMLS. ${ }^{7}$ Dental laboratories prefer using alloyed powders for fabricating frameworks for metal-ceramic restorations due to higher mechanical properties and bond strength to porcelain. ${ }^{12}$ Among them, $\mathrm{Co}-\mathrm{Cr}$ alloys are chosen since they are corrosion resistant and provide high porcelain bond strength. ${ }^{13}$

$\mathrm{Ni}-\mathrm{Cr}$ alloys have been widely used for conventional casting since they provide advantages in casting ability. Porcelain bond strength to $\mathrm{Ni}-\mathrm{Cr}$ alloys is comparable to noble alloys. However, these advantages can be produced in the existence of Beryllium. Beryllium containing $\mathrm{Ni}-\mathrm{Cr}$ alloys are no longer used due to concerns on systemic effects. But still, $\mathrm{Ni}-\mathrm{Cr}$ alloys without Be are largely used in casting metal-ceramic restorations. ${ }^{14}$

Metal-ceramic bond strength studies in the literature largely focused on comparing bond strength of dental porcelain to laser sintered and cast $\mathrm{Co}-\mathrm{Cr}$ alloys. Bae et al compared the metal ceramic bond strength of selective laser sintered and cast $\mathrm{Co}-\mathrm{Cr}$ alloy. ${ }^{15}$ Li et al investigated the bond strength of dental porcelain to milled, cast and laser sintered Co$\mathrm{Cr}$ alloys and found no difference with adequate bond strength for all test groups according to ISO standards. ${ }^{16}$ A very recent study compared the bond strength and elastic modulus of cast and laser sintered frameworks. ${ }^{17}$ Neither the elastic modulus nor the bond strength values of compared groups were different. Kaleli et al evaluated the bond strength of dental porcelain to metal bars fabricated by casting, milling, laser sintering and laser cusing and reported that all values were above the bond strength values determined by ISO-9693 standards. ${ }^{18}$ Bond strength of laser sintered $\mathrm{Co}-\mathrm{Cr}$ alloys to dental porcelain has been compared with cast Co-Cr alloys. ${ }^{15,16,18}$ However, 3-Point Bending (3PB) bond strength of $\mathrm{Ni}-\mathrm{Cr}$ alloy and dental porcelain has not been compared with laser sintered $\mathrm{Co}-\mathrm{Cr}$ thoroughly. There is only one study in dental literature comparing the bond strength of $\mathrm{Ni}-\mathrm{Cr}$ alloy with cast $\mathrm{Co}-\mathrm{Cr}$ and laser sintered $\mathrm{Co}-\mathrm{Cr}$ alloy. ${ }^{19}$ However, rather than ISO suggested 3PB test, shear test was used to compare bond strength of dental porcelain to cast $\mathrm{Ni}-\mathrm{Cr}$ and $\mathrm{Co}-\mathrm{Cr}$ alloys with laser sintered $\mathrm{Co}-\mathrm{Cr}$ alloys.

Various test methods can be used for determining porcelain bond strength to metal alloys. Shear test, tensile test, combination shear-tension test, bending (flexure) test and torsion test are commonly used. All test methods have some drawbacks about measuring the bond strength. ${ }^{20}$ However, ISO 9693-2012 test standard encourages using 3-point bending test for determining porcelain bond strength to dental alloys.

The aim of the current study was to evaluate and compare 3PB bond strength and bending modulus of dental porcelain to metals fabricated using laser sintered $\mathrm{Co}-\mathrm{Cr}$ and conventionally cast $\mathrm{Co}-\mathrm{Cr}$ and $\mathrm{Ni}-\mathrm{Cr}$ alloys. The null hypothesis was set as "there is no difference between bond strength of dental porcelain to metals fabricated using laser sintered $\mathrm{Co}-\mathrm{Cr}$ and conventionally cast $\mathrm{Co}-\mathrm{Cr}$ and $\mathrm{Ni}-\mathrm{Cr}$ alloys".

\section{MATERIAL AND METHODS}

The compositions of the alloys used in the

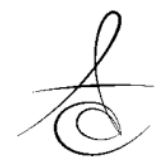


current study are given in Table 1 . Bar shaped $\mathrm{Co}-\mathrm{Cr}$ specimens were prepared according to ISO 9693 (2012) standards using DMLS (EOSINT 270, EOS $\mathrm{GmbH}$, Munchen, Germany). Specimens were manufactured in a large-scale dental laboratory (Dental Labor, Izmir, TURKEY). The specifications of DMLS were based on the standard methods recommended by the manufacturer as presented in Table 2. Metal bar dimensions were precisely measured with a digital caliper (Mitutuyo Corp, Kanagawa, Japan) to confirm the final sizes.

For preparation of cast specimens, a vinyl polysiloxane impression mold was prepared by using one of the bar specimens in DMLS group. Wax patterns were produced by filling this mold with inlay wax. The wax patterns were then cast by centrifugation according to manufacturer's recommendations using both $\mathrm{Co}-\mathrm{Cr}$ and $\mathrm{Ni}-\mathrm{Cr}$ alloys. The investment and oxide layer were cleaned with 4.5 atm air pressure, using $50 \mu \mathrm{m}$ aluminum oxide particles for 10 seconds from a $10 \mathrm{~cm}$ distance.

The bars of all test groups were cleaned using steam spray for 6 seconds, followed by immersion in ethyl acetate. The application of the porcelain-bonding agent (3C-Bond, Ceka Attachments Preci-Line, Waregem, Belgium), opaque and body porcelain layers (Super porcelain EX-3, Noritake Dental Supply Co, Ltd, Miyoshi, Japan) followed the recommendations of the manufacturers. Porcelain was applied at the center of metal bars with standard $8 \mathrm{~mm} \times 3 \mathrm{~mm} \times 1 \mathrm{~mm}$ dimensions using a custom-fabricated device. (Fig 1)
Three point bending test was performed using a universal testing machine (M500 25kN, Testometric Co, Rochdale, UK) with a crosshead speed of 1 $\mathrm{mm} / \mathrm{min}$. (Fig 2) The bond strength (units of $\mathrm{MPa}$ ) was calculated by the equation below;

" $\mathrm{T}_{\mathrm{b}}=\mathrm{k} \times \mathrm{F}_{\text {(fail)" }}$

$\mathrm{T}_{\mathrm{b}=}$ bond strength in $\mathrm{MPa}$;

$\mathrm{k}\left(\mathrm{mm}^{-2}=\mathrm{a}\right.$ constant which is a function of the metal specimen thickness $\mathrm{d}_{M}(\mathrm{~mm})$ and its elastic modulus $\mathrm{E}_{\mathrm{M}}(\mathrm{GPa})$.

$F_{\text {(fail) }}(N)=$ the peak load detected by the universal testing device.

Elastic modulus was calculated for specimens by the formula below;

$$
E=\frac{\mathrm{L}^{3} \Delta \mathrm{P}}{4 \mathrm{bh}^{3} \Delta \mathrm{d}}
$$

$\mathrm{E}=$ the elastic modulus,

$\mathrm{L}=$ the distance between supports $(20 \mathrm{~mm})$,

$B=$ the specimen width $(3 \mathrm{~mm})$,

$\mathrm{h}=$ the specimen thickness for metal $(0.5 \mathrm{~mm})$,

$\Delta \mathrm{P}$ and $\Delta \mathrm{d}$ are the load and deflection increments between 2 specific points in the elastic portion of the curves.

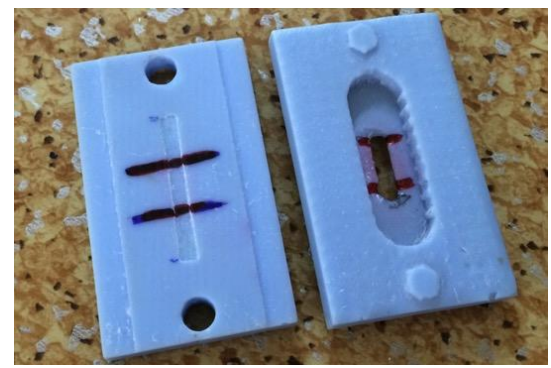

Fig 1. Device for standardization of porcelain on metal bars.

Table 1. Alloy compositions given by the manufacturer (\%).

\begin{tabular}{|l|l|l|l|l|l|l|l|l|l|l|}
\hline & Co & Cr & Mo & Si & Nb & W & Ni & C & Fe & Ce \\
\hline NiCr (Wiron 99) & - & 22.25 & 9.55 & - & 1 & - & 65 & 0.02 & 0.5 & 0.5 \\
\hline CoCr (WBC 9581) & 61 & 26 & 6 & $<2$ & - & 5 & - & - & $<2$ & $<2$ \\
\hline EOS CoCr SP2 & $61.8-65.8$ & $28-30$ & $5-6$ & $<1$ & $<0.1$ & - & $<0.1$ & $<0.02$ & $<0.5$ & - \\
\hline
\end{tabular}

Table 2. Device specifications of DMLS.

\begin{tabular}{|l|l|l|l|l|l|}
\hline & $\begin{array}{l}\text { Energy Used, } \\
(\mathbf{W})\end{array}$ & $\begin{array}{l}\text { Scan Speed, } \\
(\mathbf{m} / \mathbf{s e c})\end{array}$ & $\begin{array}{l}\text { Production } \\
\text { Speed, } \\
\left(\mathbf{m}^{\mathbf{3}} / \mathbf{s e c}\right)\end{array}$ & $\begin{array}{l}\text { Spot Laser } \\
\text { Diameter, } \\
(\boldsymbol{\mu m})\end{array}$ & $\begin{array}{l}\text { Layer } \\
\text { Thickness, } \\
(\boldsymbol{\mu m})\end{array}$ \\
\hline EOSINT M 270 & 185 & 7 & 20 & $100-500$ & $20-100$ \\
\hline
\end{tabular}




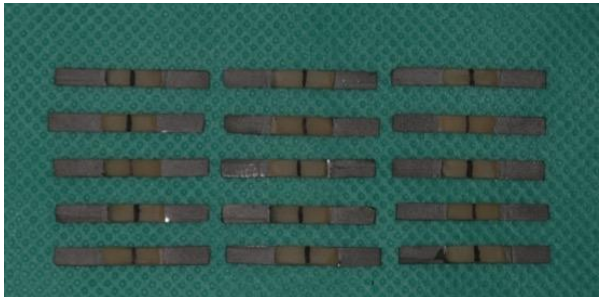

Fig 2. Laser sintered test specimens ready for 3-pointbending test.

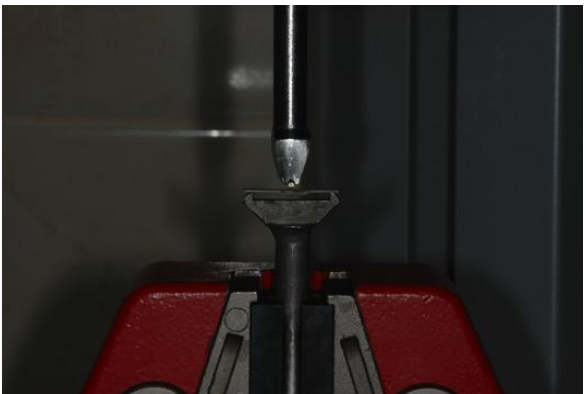

Fig 3. 3-point-bending test assembly.

\section{Statistical analysis}

The collected data from all groups were imported to Statistical Package for Social Sciences (SPSS) for Windows software, version 21.0 (SPSS Inc., Chicago, IL, USA). The standard descriptive methods were applied to determine the characteristics of the sample. Because the distribution of the data met the requirements for normality and homogeneity of variances assumptions, one-way ANOVA followed by Tukey HSD multiple comparison test $(\alpha=.05)$ were used for the multiple and pairwise comparisons, respectively. The confidence interval was set to $95 \%$ and $p<0.05$ was considered statistically significant.

\section{RESULTS}

Mean 3-point bending strength and bending modulus were statistically significantly different among 3 groups $(P=.0001)$ (Table 3$)$. The highest 3PB bond strength value was observed for laser sintered $\mathrm{Co}-\mathrm{Cr}$ group $(87 \pm 9 \mathrm{MPa})$. Although the mean 3PB strength value of cast $\mathrm{Co}-\mathrm{Cr}$ group ( $78 \pm 13 \mathrm{MPa}$ ) was lower than the laser sintered group, the difference was not statistically significant $(P=.094)$. However, the mean $3 \mathrm{~PB}$ bond strength of cast $\mathrm{Ni}-\mathrm{Cr}(45 \pm 11 \mathrm{MPa})$ was significantly lower than the Co-Cr groups ( $P=.0001)$. The lowest mean bending modulus was observed for laser sintered $\mathrm{Co}-\mathrm{Cr}$ group $(77 \pm 6.5 \mathrm{GPa})$, the highest value was observed for cast Co-Cr group (247 \pm 16 $\mathrm{GPa}$ ). Pairwise comparisons have shown statistically significant differences between all compared groups.

Table 3. Bending modulus and 3-point bending strength values.

\begin{tabular}{|l|c|cl|ll|}
\hline & N & \multicolumn{2}{|c|}{$\begin{array}{c}\text { Bending Modulus } \\
(\mathbf{M e a n} \pm \text { SD)(GPa) }\end{array}$} & \multicolumn{2}{|c|}{$\begin{array}{c}\text { Bond Strength } \\
(\mathbf{M e a n} \pm \mathbf{S D})(\mathbf{M P a})\end{array}$} \\
\hline Cast Ni-Cr & 15 & $178 \pm 36$ & $\mathrm{~B}^{*}$ & $45 \pm 11$ & $\mathrm{~A}$ \\
\hline Cast $\mathrm{Co}-\mathrm{Cr}$ & 15 & $247 \pm 60$ & $\mathrm{~A}$ & $78 \pm 13$ & $\mathrm{~B}$ \\
\hline Lazer Co-Cr & 15 & $77 \pm 65$ & $\mathrm{C}$ & $87 \pm 9$ & $\mathrm{~B}$ \\
\hline
\end{tabular}

*: Different capital letters represent statistically significant differences.

\section{DISCUSSION}

The results of the study reject the null hypothesis. Both 3PB bond strength and the bending modulus of 3 groups were statistically significantly different.

The mean bending modulus of laser sintered Co- $\mathrm{Cr}$ group was the lowest $(77 \pm 6.5 \mathrm{GPa})$. However, the same group had the highest bond strength value $(87 \pm 9 \mathrm{MPa})$. Although the controversy between the two evaluated parameters was interesting, the result was possible. The higher bond strength of the lasersintered group can be attributed to the similarity between the elastic modulus of feldspathic porcelain ( $\approx 65 \mathrm{GPa}$ ) and the 3PB specimens prepared using laser sintering.

There are numerous papers in the literature evaluating the bond strength of laser sintered metal frameworks to porcelain. ${ }^{7,12,15-19}$ The comparisons were always made with either the cast or milled $\mathrm{Co}-\mathrm{Cr}$ alloys. The bond strength was compared with cast Ni$\mathrm{Cr}$ alloys only in one study ${ }^{19}$. It is important to point out that Akova et al evaluated the bond strength using shear bond test. ${ }^{19}$ Nevertheless, ISO requires using 3PB test to evaluate the metal-ceramic bond rather than a shear test. Therefore, the results of the current study nicely fill the gap in the literature.

Akova et al reported that there was no statistically significant difference between the shear bond strength of laser sintered group and the cast Co$\mathrm{Cr}$ and $\mathrm{Ni}-\mathrm{Cr}$ groups. ${ }^{19}$ However, the highest mean bond strength values were observed for cast $\mathrm{Ni}-\mathrm{Cr}$ group, while the lowest mean bond strength was reported for the laser sintered $\mathrm{Co}-\mathrm{Cr}$ group. Exactly

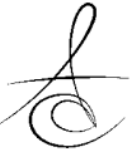


opposite results were observed for current study although exactly the same 3 groups were compared. The difference can be attributed to different test methods used for evaluating the bond strength. Until an appropriate bond test method simulating the clinical conditions is established, ISO requirement has to be prioritized.

Bond strength values reported in the current study are in accordance with the Ekren et al (7) paper. However, the results were relatively higher compared to some other papers ${ }^{16-18}$. The difference can be attributed to the different equipment or different alloys used. Nevertheless, results of the current study is in agreement with all reported values that all tested groups were higher than the accepted minimum bond strength value of $25 \mathrm{MPa}$ (ISO 1963-2012). The bending modulus was reported only in Dimitriadis et al paper where the bending test was done on alloy specimens with no ceramic applied. ${ }^{17}$ The bending results reported in the current study were obtained for metal-ceramic specimens. Bending solely the alloy gives a different bending modulus value compared to the same alloy loaded with ceramic.

Although ISO 9693-2012 requires 3PB test to be used for evaluating metal ceramic bond strength, the method is unable to simulate the stresses created on the metal ceramic interface during actual function of a crown since the nature of the stresses created in a 3PB specimen is completely different in nature compared to the stresses created in a metal ceramic crown. This is attributed to the differences in geometry of a crown and a 3PB test specimen. So far no in vitro bond strength test method has been able to exactly simulate the stresses created during chewing. Precise simulation of clinical conditions during in vitro tests is the main limitation of the current study as well. On the other hand, 3PB test is a static way of measuring the bond rather than a dynamic loading test method simulating the chewing. Therefore, the study also lacks to evaluate the effect of repeated cycles on the bond strength. However, conducting a fatigue test was out of the scope of the current study.

No thermal cycling was applied in our study. This can be pointed out as a limitation of the study. However, all groups were tested in the same condition. Therefore, the results of the study are satisfactory.

\section{CONCLUSION}

Within the limitations of this study it can be concluded that the bond strength of laser sintered Co$\mathrm{Cr}$ alloy to dental ceramic is as good as or even better than the bond strength of cast alloys.

Yurdanur Uçar: ORCID ID: 0000-0003-0505-8685

Elif Figen Koçak: ORCID ID: 0000-0002-0965-0400

Orhun Ekren: ORCID ID: 0000-0002-3237-8003

\section{REFERENCES}

1. Naylor PW. Introductıon to metal-ceramic technology, 3 rd ed. Berlin; Quintessence publishing Co Inc: 2017. p. 109.

2. White SN, Ho L, Caputo AA, Goo E. Strength of porcelain fused to titanium beams. J Prosthet Dent 1996;75:640-8.

3. O'Brien WJ. Dental Materials and Their Selection. $4^{\text {th }}$ ed. Chicago; Quintessence Publishing Co Inc: 2008. p. 531.

4. Anusavice KJ, Shen C, Rawls RH. Phillips' science of dental materials. $12^{\text {th }}$ ed. St Louis; Elsevier Inc. Saunders; 2013. p. 418-73.

5. Ucar Y, Aksahin Z, Kurtoglu C. Metal ceramic bond after multiple castings of base metal alloy. J Prosthet Dent 2009;102:165-71.

6. Naylor PW. Introduction to metal-ceramic technology, 3 rd ed. Berlin; Quintessence publishing Co Inc: 2017. p. 18.

7. Ekren O, Ozkomur A, Ucar Y. Effect of layered manufacturing techniques, alloy powders, and layer thickness on metal-ceramic bond strength. J Prosthet Dent.2018;119:481-7.

8. Uçar Y, Aysan Meriç I, Ekren O. Layered Manufacturing of Dental Ceramics: Fracture Mechanics, Microstructure, and Elemental Composition of Lithography-Sintered Ceramic. J Prosthodont 2019;28:310-18.

9. Koutsoukis T, Zinelis S, Eliades G, Al-Wazzan K, Rifaiy MA, Al Jabbari YS. Selective Laser Melting Technique of Co-Cr Dental Alloys: A Review of Structure and Properties and Comparative Analysis with Other Available Techniques. J Prosthodont 2015;24:303-12.

10. Yıldırım MP, Bayındır F. Protetik diş tedavisinde hızlı prototip üretim teknolojileri Atatürk Üniv Diş Hek Fak Derg 2013;25:430-35. 
11. Mazzoli A. Selective laser sintering in biomedical engineering. Med Biol Eng Comput 2013;51:24556.

12. Ren XW, Zeng L, Wei ZM, Xin XZ, Wei B. Effects of multiple firings on metal-ceramic bond strength of Co-Cr alloy fabricated by selective laser melting. J Prosthet Dent 2016;115:109-14.

13. Nesse $H$, Ulstein DM, Vaage MM, Øilo M. Internal and marginal fit of cobalt-chromium fixed dental prostheses fabricated with 3 different techniques. J Prosthet Dent. 2015;114:686-92.

14. Naylor PW. Introduction to metal-ceramic technology, 3 rd ed. Berlin; Quintessence publishing Co Inc: 2017. p. 53.

15. Bae EJ, Kim JH, Kim WC, Kim HY. Bond and fracture strength of metal-ceramic restorations formed by selective laser sintering. J Adv Prosthodont 2014;6:266-71.

16. Li J, Chen C, Liao J, Liu L, Ye X, Lin S, Ye J. Bond strengths of porcelain to cobalt-chromium alloys made by casting, milling, and selective laser melting. J Prosthet Dent 2017;118:69-75.

17. Dimitriadis K, Spyropoulos K, Papadopoulos T. Metal-ceramic bond strength between a feldspathic porcelain and a Co-Cr alloy fabricated with Direct Metal Laser Sintering technique. J Adv Prosthodont 2018;10:25-31.

18. Kaleli N,Sarac D. Comparison of porcelain bond strength of different metal frameworks prepared by using conventional and recently introduced fabrication methods. J Prosthet Dent 2017;118:7682.

19. Akova T, Ucar Y, Tukay A, Balkaya MC, Brantley WA. Comparison of the bond strength of lasersintered and cast base metal dental alloys to porcelain. Dent Mater 2008;24:1400-4.

20. HammadIA,TalıcYF. Designs of bond strength tests for metalceramic complexes: review of the literature. J Prosthet Dent 1996;75:602-8.

\author{
Yazışma Adresi \\ Orhun Ekren \\ Cukurova University, Faculty of \\ Dentistry,Department of Prosthodontics, \\ Balcalı/Sarıcam Adana/Turkiye \\ Tel: $+90(533) 7175954$ \\ Fax: $+90(322) 3387331$
}

e-mail: oekren@cu.edu.tr 